\title{
Immune activation is associated with decreased thymic function in asymptomatic, untreated HIV- infected individuals
}

\begin{tabular}{|c|c|}
\hline \multicolumn{2}{|c|}{$\begin{array}{l}\text { Authors: } \\
\text { Thandiwe Manjati }{ }^{1,2} \\
\text { Bongani Nkambule } \\
\text { Hayley Ipp }{ }^{1,2}\end{array}$} \\
\hline \multicolumn{2}{|c|}{$\begin{array}{l}\text { Affiliations: } \\
{ }^{1} \text { Division of Haematology, } \\
\text { Department of Pathology, } \\
\text { Stellenbosch University, } \\
\text { South Africa }\end{array}$} \\
\hline \multicolumn{2}{|c|}{$\begin{array}{l}{ }^{2} \text { Division of } \\
\text { Haematopathology, National } \\
\text { Health Laboratory Service, } \\
\text { Tygerberg Hospital, Cape } \\
\text { Town, South Africa }\end{array}$} \\
\hline \multicolumn{2}{|c|}{$\begin{array}{l}{ }^{3} \text { Department of Physiology, } \\
\text { School of Laboratory and } \\
\text { Medical Sciences, University } \\
\text { of KwaZulu-Natal, } \\
\text { South Africa }\end{array}$} \\
\hline \multicolumn{2}{|c|}{$\begin{array}{l}\text { Corresponding author: } \\
\text { Thandiwe Manjati, } \\
\text { thandiwe.manjati@nhls.ac.za }\end{array}$} \\
\hline \multicolumn{2}{|c|}{$\begin{array}{l}\text { Received: } 10 \text { Nov. } 2015 \\
\text { Accepted: } 25 \text { May } 2016 \\
\text { Published: } 28 \text { July } 2016\end{array}$} \\
\hline \multicolumn{2}{|c|}{$\begin{array}{l}\text { How to cite this article: } \\
\text { Manjati T, Nkambule B. } \\
\text { Immune activation is } \\
\text { associated with decreased } \\
\text { thymic function in } \\
\text { asymptomatic, untreated } \\
\text { HIV-infected individuals. S Afr } \\
\text { J HIV Med. 2016;17(1), a445. } \\
\text { http://dx.doi.org/10.4102/ } \\
\text { sajhivmed.v17i1.445 }\end{array}$} \\
\hline \multicolumn{2}{|c|}{$\begin{array}{l}\text { Copyright: } \\
\text { (c) 2016. The Authors. } \\
\text { Licensee: AOSIS. This work } \\
\text { is licensed under the } \\
\text { Creative Commons } \\
\text { Attribution License. }\end{array}$} \\
\hline \multicolumn{2}{|l|}{ Read online: } \\
\hline 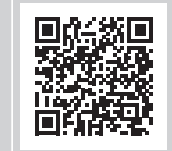 & $\begin{array}{l}\text { Scan this QR } \\
\text { code with your } \\
\text { smart phone or } \\
\text { mobile device } \\
\text { to read online. }\end{array}$ \\
\hline
\end{tabular}

Authors:

niwe Manjati

Affiliations:

Division of Haematology, Stellenbosch University,

South Africa

${ }^{2}$ Division of

'Divisionatopathology, National

Tygerberg Hospital, Cape

of KwaZulu-Natal,

Corresponding author:

Thandiwe Manjati,

Dates:

Received: 10 Nov. 2015

Accepted: 25 May 2016

How to cite this article:

Manjati T, Nkambule B.

Immune activation is

associated with decreased

thymic function in

ymptomatic, untreate

J HIV Med. 2016;17(1), a445.

http://dx.doi.org/10.4102/

Copyright:

(C) 2016. The Authors.

Licensee: AOSIS. This work

is licensed under the

Creative Commons

Attribution License.

mobile device
Background: Reduced thymic function causes poor immunological reconstitution in human immunodeficiency virus (HIV)-positive patients on combined antiretroviral therapy (cART). The association between immune activation and thymic function in asymptomatic HIVpositive treatment-naive individuals has thus far not been investigated.

Aims and objectives: To optimise a five-colour flow cytometric assay for measurement of thymic function by measuring recent thymic emigrants (RTEs) in treatment-naive HIV-infected patients and healthy controls and correlate results with levels of immune activation, CD4 counts and viral load.

Methods: Blood obtained from 53 consenting HIV-positive individuals and 32 controls recruited from HIV prevention and testing clinic in Cape Town, South Africa. RTEs were measured $\left(\mathrm{CD}^{+} / \mathrm{CD}^{+} / \mathrm{CD} 45 \mathrm{RA}^{+} / \mathrm{CD} 31^{+} / \mathrm{CD} 2 \mathrm{~L}^{+}\right)$and levels were correlated with $\mathrm{CD} 4$ counts of HIV-infected individuals, log viral load and levels of immune activation $\left(\mathrm{CD}^{+} /\right.$ CD38+ T-cells).

Results: HIV-infected individuals had reduced frequencies of RTEs when compared to controls $(p=0.0035)$. Levels of immune activation were inversely correlated with thymic function $(p=0.0403)$, and the thymic function in HIV-infected individuals showed no significant correlation with CD4 counts $(p=0.31559)$ and viral load $(p=0.20628)$.

Conclusions: There was impaired thymic function in HIV-infected individuals, which was associated with increased levels of immune activation. The thymic dysfunction was not associated with CD4 counts and viral load. Immune activation may result in inflammatory damage to the thymus and subsequent thymic dysfunction, and CD4 counts and viral load may not necessarily reflect thymic dysfunction in HIV.

\section{Introduction}

\section{Background}

Human immunodeficiency virus (HIV) infection is characterised by depletion of naive and memory CD4 T-cells due to its ability to damage both thymic and peripheral T-cell homeostasis. In addition, there is evidence of direct infection of thymocytes by HIV, which results in defective thymopoiesis and apoptosis of CD4 T-cells. ${ }^{1,2}$

Within a year of initiation of combined antiretroviral therapy (cART), the thymus of adult HIVpositive patients on CART expands, ${ }^{3}$ and evidence has shown that infected adults' thymuses are still functional despite physiological involution. Therefore, the thymus plays a role in immune recovery or contributes to the lack of immune reconstitution in HIV-infected patients. ${ }^{4}$ In some studies, it has been shown that immune reconstitution in adults is mainly from the memory T-cell pool, whereas in children, it is mainly from the naive T-cell subset. ${ }^{5}$

\section{Literature review}

Most studies that have assessed thymic output in HIV patients have shown reduced output prior to initiating cART and significant thymic output increase after therapy initiation. ${ }^{4,5,6,7}$

The ongoing viraemia prior to cART initiation may cause proliferation of recent thymic emigrants (RTEs) and result in differentiation to memory T-cells, which are more susceptible to HIV-1 infection than naive T-cells. This, in addition to reduced thymic function, reduces the number of 
RTEs in HIV infection. ${ }^{8}$ In addition to improved thymic function, another mechanism for the increase seen after initiation of CART is the release of lymphocytes that have been sequestered in lymphoid tissue during HIV replication. ${ }^{7}$ The effect of the increase due to memory T-cells redistributed from lymph nodes wanes after a few weeks of therapy, and the increase due to the production of new naive T-cells derived from thymopoiesis is maintained for a longer period. ${ }^{6,9}$

This entrapment of RTEs in lymphoid tissue was particularly seen in individuals with high viral loads. ${ }^{10}$

\section{Immune activation in HIV infection}

Chronic infections such as HIV infection are associated with chronic inflammation that may be systemic, affecting the whole body and leading to persistent immune activation with CD4 T-cell activation and turnover. ${ }^{11,12}$ Immune dysregulation causes a sustained increase in pro-inflammatory cytokines and erosion of immune defences. Persistent T-cell activation accelerates their maturation, cell growth and division. Immune activation in HIV leads to premature T-cell 'burn out' or clonal exhaustion and apoptosis. ${ }^{11,12}$

An important mechanism contributing to immune activation is the early damage to the gastrointestinal mucosa, which results in the ongoing translocation of microbes and microbial products into the systemic circulation. ${ }^{12}$ This is one of the causes of poor immune recovery after cART..$^{1,12,13}$ Chronic immune activation in HIV results in poor immune recovery and thus poor outcome and faster disease progression as well as end organ complications. ${ }^{12}$ Chronic immune activation in HIV causes increased proliferation of thymocytes, which in the long term causes clonal exhaustion of T-cells and inflammatory damage to the lymphoid tissue. ${ }^{1,12}$ Patients with a large thymus have shown a better immune reconstitution when compared with those with a small thymus; therefore, thymopoiesis is important in immune reconstitution. Initiating therapy whilst thymic function is still good may be important in order to improve clinical outcomes. ${ }^{13}$ There are only few studies that have linked immune activation to thymic dysfunction in HIV-infected people. ${ }^{14}$

\section{CD31 and CD62L cell markers}

CD31 is a cell surface marker expressed preferentially by naive, T-cell receptor excision circle (TREC)-rich T-cells that have undergone a low number of T-cell divisions; therefore, CD31 can be used as a marker for RTEs. ${ }^{15,16,17,18,19}$ It is a $130-\mathrm{kDa}$ transmembrane glycoprotein expressed by endothelial cells, platelets, monocytes, neutrophils and certain T-cell subsets. The average TREC content in $\mathrm{CD}^{+} / \mathrm{CD}^{+} / \mathrm{CD} 45 \mathrm{RA}^{+} /$ $\mathrm{CD} 1^{+} / \mathrm{CD} 2 \mathrm{~L}^{+} \mathrm{T}$-cells is 18 times higher than in $\mathrm{CD}^{+} /$ $\mathrm{CD}^{+} / \mathrm{CD} 45 \mathrm{RA}^{+} / \mathrm{CD} 31^{-} / \mathrm{CD} \mathrm{L}^{+}$T-cells confirming the strong correlation between $\mathrm{CD} 31$-expressing naive $\mathrm{CD} 4$ T-cells and the presence of TREC. ${ }^{15}$ CD31 is downregulated on the majority of CD4 T-cells upon their transition to the memory phenotype..$^{15}$ A progressive decrease of percentages and absolute numbers of RTEs has been found associated with ageing, and in addition, CD31 is downregulated during homeostatic expansion of naive T-cells. ${ }^{13}$

CD62L (L-selectin) is an adhesion molecule that allows T-cells to enter secondary lymphoid tissues via high endothelial venules. Early studies showed that bright CD62L expression was also a marker found on RTEs. ${ }^{20,21,22}$ It is expressed by naive T-cells and central memory T-cells and is absent on effector memory T-cells. It is upregulated by thymocytes ${ }^{23}$ and plays an essential role in lymphocyte homing to lymphoid tissue and sites of inflammation..$^{23,24}$

Immune activation at the thymic site may result in inflammatory damage to the thymus and subsequent thymic dysfunction. ${ }^{1}$ This study investigated HIV-positive individuals who were not yet started on CART and measured thymic function using flow cytometry (CD31 and CD62L) as well as levels of immune activation (CD38 expression on CD8 T-cells).

\section{Research design Research approach and methods}

This was a cross-sectional study of 53 consenting, untreated asymptomatic HIV-infected black South African adults and 32 uninfected controls aged $>21$ years. The study was approved by the University of Stellenbosch, Faculty of Health Sciences, Human Research Ethics Committee (HREC N07/09/197). Patients and controls were recruited from an HIV prevention and testing clinic in Cape Town, South Africa. All individuals gave informed consent prior to their involvement in the study. Whole blood samples of $4 \mathrm{~mL}$ were collected from patients and controls into a heparin tube for measurement of RTEs and levels of immune activation, and $5 \mathrm{~mL}$ of blood was collected into an EDTA tube for CD4 count and viral load.

\section{Measurement of recent thymic emigrant frequency using flow cytometry}

The cell surface molecule expression was monitored by staining cells with the following fluorochrome-labelled monoclonal antibodies: CD31 FITC 5.6E, CD4 PE 13B8.2, CD45RA ECD J.33, CD62L PC5 DREG56 and CD3PC7 UCHT1. The optimal volumes of each antibody were mixed in a $5 \mu \mathrm{L}$ cocktail and titrated in dilution experiments. The samples with $50 \mu \mathrm{L}$ of heparinised blood and antibody cocktail were then incubated in the dark for $15 \mathrm{~min}$ at room temperature. Five hundred microlitres of phosphate-buffered saline (PBS) staining buffer was added and samples were analysed immediately. Data acquisition was done using the Beckman Coulter FC500 five-colour flow cytometer Calibur and CXP software.

\section{Gating strategy}

The cell type and size were identified by size, granularity and positive expression of surface markers CD31, CD62L and CD45RA specific for RTEs on CD4 T-cells. Initial gating was performed on CD3-positive population with low side 
scatter (T-cells). Secondary gating of CD45RA-positive cells and CD4-positive cells from the CD3-positive T-cells was done. CD3/CD45RA/CD4-positive naive T-cells were further analysed for CD31- and CD62L-positivity (RTEs). Controls or populations of cells negative for CD31 and CD62L were used to establish the 'cut-off' values for CD31and CD62L-positivity. RTEs were described as $\mathrm{CD}^{+} / \mathrm{CD}^{+} /$ $\mathrm{CD}_{5} 5 \mathrm{RA}^{+} / \mathrm{CD} 1^{+} / \mathrm{CD} 2 \mathrm{~L}^{+} \mathrm{T}$-cells. Levels of expression of these markers were correlated with CD4 counts, viral loads, levels of activation and patient's age using Spearman's R test.

\section{CD4 T-cell count and viral load measurements}

The BD MultiTEST CD3-FITC/CD8-PE/CD45-PerCP/CD4APC reagent and BD TruCOUNT tubes (BD Biosciences, San Jose, CA) were utilised for the measurement of CD4 T-cell count. For viral load measurements, blood samples were collected into $5 \mathrm{~mL}$ EDTA tubes, which were centrifuged at $20^{\circ} \mathrm{C}$ at $300 \mathrm{~g}$ for $12 \mathrm{~min}$. One millilitre of plasma was transferred into a Greiner Bio-one cryotube (Greiner Bio-One $\mathrm{GmbH}$, Frickenhausen, Germany) and sent for viral load testing. The viralload assay performed was a NucliSensEasy $Q^{\circledR}$ HIV-1 v1.2 Viral Load Test (BioMerieux Inc., Boxtel, the Netherlands), which has a detection range of 1.60-6.7 $\log _{10}$ copies/mL. Both these tests were performed at the Division of Medical Virology, Faculty of Health Sciences, Stellenbosch University, which is accredited by the South African National Accreditation System (SANAS).

\section{Measurements of the percentage of CD8+ T-cells expressing CD38}

This measurement was performed using flow cytometry. Briefly, $50 \mu \mathrm{L}$ of heparinised whole blood was stained with a titrated monoclonal antibody cocktail containing CD8 PerCP, CD38 APC and CD3 FITC (BD Biosciences, San Jose, CA). Data acquisition was performed using a BD FACS Calibur instrument, and analysis was done using the BD Cell Quest Pro (Version 2) software.

\section{Statistical analysis}

The software used for statistical analysis was Graph Pad Prism version 5.0 for Windows, Graph Pad software, CA, USA. Mann-Whitney $U$ test was used to determine $\% \mathrm{CD} 38^{+} / 8^{+} \mathrm{T}$-cells (levels of immune activation) and reported as the median and interquartile range, and unpaired $t$-test was used to determine $\% \mathrm{CD}^{+} / \mathrm{CD}^{+} / \mathrm{CD} 4 \mathrm{RA}^{+} / \mathrm{CD} 2 \mathrm{~L}^{+} /$ CD $31^{+}$T-cells (RTEs) between the HIV-infected and control groups and reported as mean and standard deviation. Nonparametric data of HIV-positive individuals were analysed using Spearman's $R$ correlations. All $p$-values were considered as significant when $<0.05$. These analyses were performed as single experiments.

\section{Results}

The cohort consisted of 85 consenting individuals with similar ages and demographics. Of these, 53 were HIVinfected individuals and 32 uninfected controls with median ages (in years): control group 27 [23-34] versus HIV group 28 [25-35], $p=0.2113$ ). Despite being clinically asymptomatic, the HIV-positive group had significantly lower CD4 counts when compared to the control group $(p<0.0001)$ as shown in Table 1 .

RTEs were significantly reduced in the HIV-infected group, with mean \% value of $40.13 \pm 21.72$ in HIV-positive group versus $54.96 \pm 20.10$ in control group ( $p=0.0035)$ (as shown in Figure 1). Immune activation levels were significantly increased in the HIV group as determined by the marker of activation, $\mathrm{CD} 38^{+} / 8^{+}$-positive T-cells, which was increased in the HIV-infected group (26.1) versus control group (8.610) with a $p$-value of $<0.0001$ (as shown in Figure 2).

Further analysis of HIV group was done using Spearman's $\mathrm{R}$ correlations for non-parametric data (as shown in Table 2).

Log viral load correlated inversely with the CD4 counts, whereas there was a direct correlation between log viral load and levels of immune activation $(r=0.431, p=0.0027)$. The

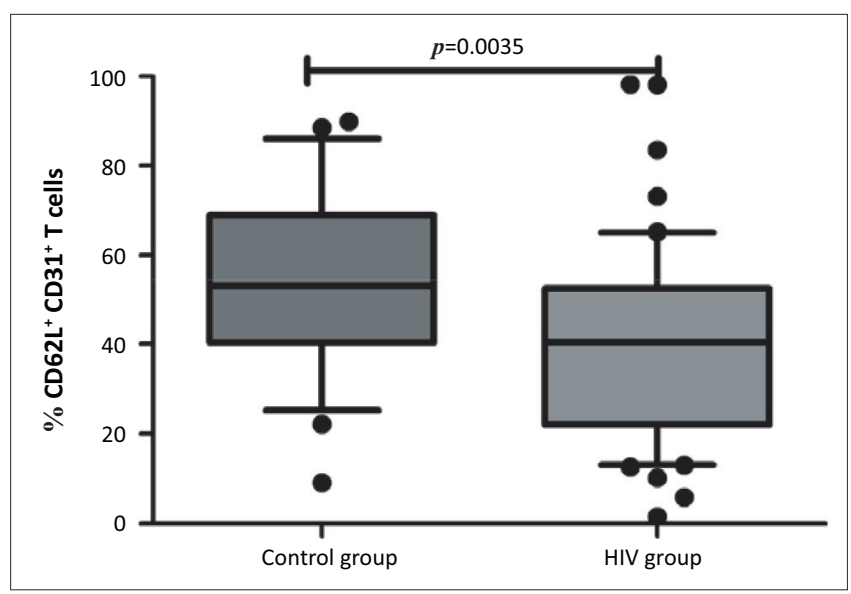

Note: Percentage of RTEs in HIV-infected group $(n=53)$ versus control group $(n=32)$. RTES were significantly reduced in the HIV-infected group, with mean $\%$ value of $40.13 \pm 21.72$ in HIV-positive group versus $54.96 \pm 20.10$ in control group $(p=0.0035)$. (The bars depict standard deviations and the lines are mean $\%$.

FIGURE 1: Baseline levels of per cent of CD4+/CD45RA+/CD62L+/CD31+ T-cells in HIV-positive versus control groups.

TABLE 1: Participants' demographics and disease parameters.

\begin{tabular}{|c|c|c|c|c|c|}
\hline \multirow[t]{2}{*}{ Parameters } & \multicolumn{2}{|c|}{ HIV infected $\dagger$} & \multicolumn{2}{|c|}{ Uninfected controls: } & \multirow[t]{2}{*}{$p$-value } \\
\hline & $n$ & Range & $n$ & Range & \\
\hline Median age (years) & 28 & $25-35$ & 27 & $23-34$ & 0.2113 \\
\hline Male: female ratio & $1: 4$ & - & $1: 1$ & - & - \\
\hline Median CD4 (cells $/ \mathrm{mm}^{3}$ ) & 354.0 & $208-503$ & 828.0 & $644.8-1123$ & $<0.0001$ \\
\hline Log viral load & 4.2705 & - & - & - & - \\
\hline $\mathrm{CD} 8^{+} / 8^{+}(\%$ cells gated $)$ & 26.14 & $6.800-12.64$ & 8.610 & $17.62-40.38$ & $<0.0001$ \\
\hline
\end{tabular}

$\dagger, n=53 ; \vdots, n=32$ 


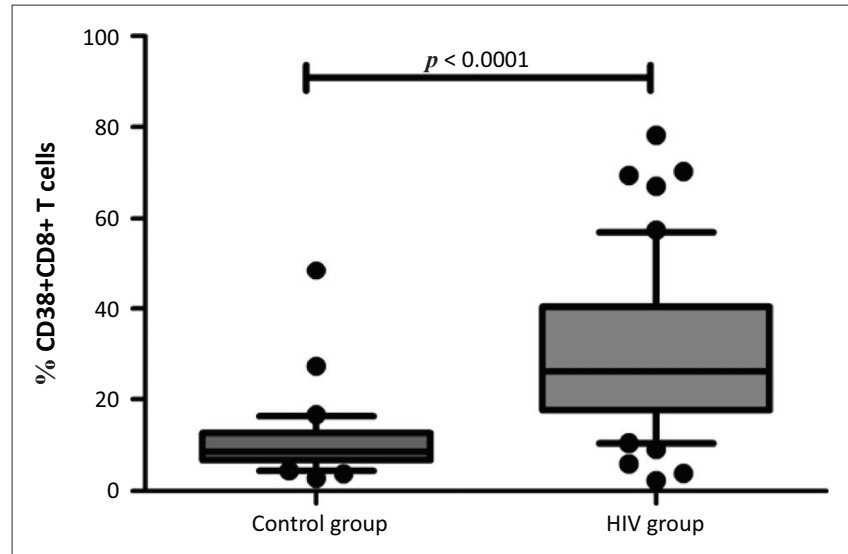

Note: Percentage of CD38+CD8+ T-cells in HIV-infected group $(n=53)$ versus control group $(n=32)$. Immune activation levels were significantly increased in the HIV-infected group (26.1) versus control group (8.610) with a $p$-value of $<0.0001$. (The bars depict interquartile ranges and the lines are median $\%$.)

FIGURE 2: Baseline levels of $\%$ of CD38+/CD8+ T-cells in HIV-positive versus control groups.

TABLE 2: Spearman's R correlations for HIV group.

\begin{tabular}{llll}
\hline $\begin{array}{l}\text { Non-parametric data for HIV } \\
\text { group }\end{array}$ & $\begin{array}{l}\text { Non-parametric data for } \\
\text { HIV group }\end{array}$ & $\boldsymbol{R}$ & $\boldsymbol{p}$-value \\
\hline CD4 count & RTEs & 0.14335 & 0.31559 \\
CD4 count & Log viral load & -0.2970 & $0.0425^{*}$ \\
CD4 count & Age & -0.2371 & 0.0938 \\
CD4 count & Levels of immune activation & -0.3977 & $0.0035^{*}$ \\
\hline RTEs & Levels of immune activation & -0.2910 & $0.0403^{*}$ \\
\hline RTEs & Age & -0.1494 & 0.3054 \\
Levels of immune activation & Log viral load & 0.4311 & $0.0027^{*}$ \\
Levels of immune activation & Age & -0.1642 & 0.2543 \\
\hline Log viral load & Age & -0.0299 & 0.8449 \\
RTEs & Log viral load & -0.19204 & 0.20628 \\
\hline
\end{tabular}

$*, p$-values are significant: $<0.005$.

CD4 count correlated inversely with levels of immune activation $(r=-0.397, p=0.0035)$.

Levels of immune activation correlated inversely with the number of RTEs ( $p=0.0403)$ in this HIV-positive group. There were no significant correlations between age in the HIVpositive cohort and other parameters such as CD4 counts, viral load, levels of immune activation and RTEs in this group, and RTEs did not show a significant correlation with the CD4 counts or the log viral load.

\section{Discussion}

RTEs refer to T-cells that have undergone only a few cellular divisions after leaving the thymus. ${ }^{25,26}$ These naive T-cells have recently exited the thymus and have not undergone peripheral T-cell proliferation and antigen selection. They have high TRECs and their numbers in peripheral blood depend on the magnitude of thymic export. ${ }^{17}$ Therefore, measuring the number of RTEs allows assessment of the thymic contribution to the peripheral T-cell pool. TREC concentrations in RTEs are affected by factors such as lymphopenic conditions, where absolute numbers of TRECs can be influenced by dilution factors due to peripheral expansion of naive and memory T-cells, for example, after haematopoietic stem cell transplantation or in HIV-infected patients after $\mathrm{CART}^{15}$; ageing also decreases the number of TRECs 50-100 fold. ${ }^{15}$ However, controversy exists as to whether TREC concentrations are a good marker for RTE, because TREC concentrations are also affected by peripheral T-cell turnover events, such as T-cell division and death. 17,27,28 In HIV infection and other lymphopenic diseases, T-cell homeostasis is maintained by the ability of the thymus to export new naive T-cells. ${ }^{29}$ Therefore, thymic function can be monitored in conditions that influence T-cell depletion and reconstitution, such as HIV-1 infection, bone marrow transplantation and immunosuppressive therapy. ${ }^{30}$

In this study, we measured RTEs using flow cytometry, with particular use of the marker CD31. We designed and optimised a flow cytometry panel that could be used as a measure of thymic function in asymptomatic, treatmentnaive HIV-infected patients. We showed that RTEs were significantly decreased in this group, even with CD4 counts median of 354 cells $/ \mathrm{mm}^{3}$ (which is $>350$ cells $/ \mathrm{mm}^{3}$ ). The treatment cut-off value in South Africa had been below 350 cells $/ \mathrm{mm}^{3}$ until recently. Furthermore, we showed for the first time to our knowledge, levels of RTEs by flow cytometry correlated inversely with immune activation levels in untreated HIV-infected individuals. This supports the concept that ongoing immune activation has a damaging effect on thymic function in untreated HIV infection. Interestingly, RTE levels did not correlate with viral load nor CD4 count suggesting that these parameters do not necessarily reflect thymic dysfunction at this stage of the disease.

Most studies that have assessed thymic output in HIV patients have shown reduced output prior to initiating cART and significant thymic output increase after therapy initiation. ${ }^{4,6,7}$ However, these studies have not shown the difference between HIV-positive individuals and uninfected controls, and CD4 counts were lower (200-300 cells $/ \mathrm{mm}^{3}$ ) and viral log levels were higher $(4.8-5.0 \log$ copies $/ \mathrm{mL})$ in comparison with our HIV-positive group. In addition, the studies that compared untreated HIV-positive individuals with uninfected controls were conducted in children.

The results of our study have highlighted previous literature findings, wherein untreated HIV-positive individuals have increased immune activation when compared to uninfected controls. ${ }^{11,31}$ Furthermore, we showed that the higher levels of immune activation (as demonstrated by the increased percentage of CD38+/CD8+ T-cells) were significantly associated with lower CD4 counts and higher viral loads.

In untreated HIV-positive individuals, the activation marker CD38 indicates rapid clinical progression of disease and death more strongly than CD4+ T-cell counts and plasma HIV RNA levels. ${ }^{32}$ There is evidence that thymic output is required to maintain efficient gut mucosal defence. ${ }^{32}$ Bourgeois et al. showed in a mouse model of chemical thymomectomy that loss of gut immunity in HIV infection, particularly Th17 cells, leads to loss of barrier integrity and 
subsequent bacterial translocation and microbial products into circulation, which results in chronic immune activation. ${ }^{29}$ These findings suggest that augmenting thymic output can be used to correct aberrant activation caused by HIV infection or HIV-induced microbial translocation. ${ }^{29,32}$

Our study findings highlight the concept that ongoing immune activation impacts thymic production of naive $\mathrm{T}$-cells thus resulting in depletion of the naive T-cell pool seen in HIV infection. This is supported by a study conducted by Bandera et al. of ex-vivo thymuses from HIV-positive individuals and uninfected controls. ${ }^{1}$ They analysed markers of T-cell differentiation and activation at different stages of thymopoiesis and found a significantly higher proportion of activated and proliferating thymocytes at all stages of thymopoiesis in HIV-infected patients compared to controls. They suggested that this increased activation and proliferation of thymocytes at the thymic site might in the long term cause clonal exhaustion of T-cells ('burn out') and damage to lymphoid tissue. ${ }^{1}$ The immune activation at the thymic site is likely caused by bystander mechanisms and sustained by homeostatic proliferation and may result in inflammatory damage leading to thymic dysfunction. ${ }^{1}$ Some studies have reported that HIV can directly infect the thymus thereby compromising its integrity. ${ }^{2,33}$ Reduced T-cell restoration has been reported to be caused by the effects of atrophy or shrinkage of the thymus. Using the simian immunodeficiency virus-infected rhesus macaques, Wykrzykowska et al. showed that in the first 7 days of infection, the thymus has a regenerative capacity with increased cell proliferation; however, from 24 weeks after infection there was evidence of severe thymic damage. ${ }^{2}$ This group concluded that the regenerative capacity of the thymus is limited in HIV infection. Early thymic dysfunction in children is also related to rapid progression to acquired immune deficiency syndrome (AIDS). ${ }^{34}$ Middle-aged people with HIV showed evidence of immunosenescence (ageing of the immune system) resembling that of HIV-negative individuals two decades older. The ongoing immune activation and inflammation due to constant stimulation by HIV or other chronic infections accelerates the process of immunosenescence. ${ }^{11,35}$

Our findings showed an association between thymic function in HIV infection and levels of immune activation. There seems to be a vicious cycle that results from immune activation causing damage to the thymus and thus causing dysfunctional thymic output. In turn, the reduced thymic output results in immune activation due to loss of mucosal barrier integrity and subsequent bacterial translocation and microbial products into circulation.

\section{Conclusion}

There is mounting evidence of the contribution by the adult thymus to immune reconstitution in HIV infection. ${ }^{1,35}$ Larger thymic size was associated with higher CD4 counts and higher thymic outputs. ${ }^{35}$ We therefore suggest that initiating cART in patients with poor thymic function could be associated with poor immunological response. This study supports earlier initiation of CART, before thymic damage or irreversible dysfunction sets in.

This use of flow cytometry markers of RTEs in conjunction with a marker of immune activation would be a valuable addition to the assessment of thymic function in these individuals. This panel could then be used to follow up thymic output after initiation of therapy. Other methods used to estimate thymic function include measurements of thymic volume using computed tomography (CT) scan and evaluation of TREC-bearing cells by quantitative polymerase chain reaction (PCR). ${ }^{3}$ However, these techniques are expensive and TREC data may be difficult to interpret. ${ }^{36}$ This study presents a robust alternative method that can be used simultaneously to measure the levels of immune activation.

Further studies on the measurement of thymic function and levels of immune activation in HIV-positive patients with CD4 counts $>500$ cells $/ \mathrm{mm}^{3}$ are recommended. This would further establish whether immune dysfunction due to decreased thymic output is occurring at even earlier stages of the infection. These studies would support the earlier intervention with ART for the protection of thymic function and better immunologic recovery. It will be important to develop novel therapeutic strategies to limit immune activation and in doing so, protect the thymus from inevitable damage and dysfunction.

\section{Potential study limitations}

This study was conducted on the black South African population group and therefore may not be representative of other racial groups in South Africa. The HIV cohort consisted of more females versus males. It is not known whether the hormonal differences between the two sexes can influence thymic function. It was also unknown how long each HIVpositive patient had been infected without treatment, and therefore, we do not know if the length of infection influences thymic output. The HIV-infected individuals are defined as being asymptomatic. Symptoms were determined by clinical questioning and examination but no further special investigations such as CXR were performed; so subclinical infections may have been missed. Finally, this was a small study group and a follow-up study on a larger cohort is considered.

\section{Acknowledgements}

This work was supported by a grant from the National Health Laboratory Service, South Africa. The principal funding recipient is Dr Hayley Ipp. The authors thank the participants and health workers for their involvement in this study. The authors especially thank their external reviewers for their drafts. The authors also acknowledge University of Stellenbosch, Beckman Coulter flow cytometry research and training laboratory facility at Tygerberg Hospital, South Africa, who provided the flow cytometer Calibur used in this study. 


\section{Competing interests}

The authors declare that they have no financial or personal relationships which may have inappropriately influenced them in writing this article.

\section{Authors' contributions}

TSM is the main author and corresponding author. She contributed to the conception and design of the study, acquisition of data (carried out flow cytometry assays), as well as analysis and interpretation of data. She also drafted the manuscript and carried out the corrections. HI participated in conception and design of the study, analysis and interpretation of data, critically revising the script and giving the final approval of the version to be published. BN participated in acquisition of data (carried out flow cytometry assays), analysis and interpretation of data, performed statistical analysis and helped in revising the script. All authors read and approved the final manuscript.

\section{References}

1. Bandera A, Ferrario G, Seresella M, et al. CD4+ T cell depletion, immune activation and increased production of regulatory T cells in the thymus of HIV infected individuals. PLoS One. 2010;5:1-8. http://dx.doi.org10.1371/journal.pone.0010788

2. Wykrzykowska J, Rosenzweig M, Veazey RS, et al. Early regeneration of thymic progenitors in rhesus macaques infected with simian immunodeficiency virus. J Exp Med. 1998;11:1767-1778. http://dx.doi.org/10.1084/jem.187.11.1767

3. Hakim FT, Memon SA, Cepeda R, et al. Age-dependent incidence, time course, and consequences of thymic renewal in adults. J Clin Invest. 2005;115:930-939. http://dx.doi.org/10.1172/JCI200522492

4. Al-Harthi L, Voris J, Patterson BK, et al. Evaluation of the impact of highly active antiretroviral therapy on immune recovery in antiretroviral naive patients. HIV Med. 2004;1:55-65. http://dx.doi.org/10.1111/j.1468-1293.2004.00186.x

5. Sandgaard KS, Lewis J, Adams S, Klein N, Callard R. Antiretroviral therapy increases thymic output in children with HIV. AIDS. 2014;2:209-214. http://dx.doi. org/10.1097/QAD.0000000000000063

6. Franco JM, Rubio A, Martínez-Moya M, et al. T-cell repopulation and thymic volume in HIV-1-infected adult patients after highly active antiretroviral therapy. Blood. 2002;10:3702-3706. http://dx.doi.org/10.1182/blood.V99.10.3702

7. Diaz $M$, Douk DC, Valdez $H$, et al. T cells containing $T$ cell receptor excision circles are inversely related to HIV replication and are selectively and rapidly released into circulation with antiretroviral treatment. AIDS. 2003;8:1145-1149. http:// dx.doi.org/10.1097/00002030-200305230-00005

8. Brenchley JM, Douek DC, Ambrozak DR, et al. Expansion of activated human naive T-cells precedes effector function. Clin Exp Immunol. 2002;3:432-440. http:// dx.doi.org/10.1046/j.1365-2249.2002.02015.x

9. Ruiz-Mateos E, de la Rosa R, Franco JM, et al. Endogenous IL-7 is associated with increased thymic volume in adult HIV-infected patients under highly active antiretroviral therapy. AIDS. 2003;7:947-954. http://dx.doi.org/10.1097/00002030200305020-00002

10. Nokta MA, Li XD, Al-Harthi L, et al. Entrapment of recent thymic emigrants in lymphoid tissues from HIV-infected patients: Association with HIV cellular viral load. AIDS. 2002;16:2119-2127. http://dx.doi.org/10.1097/00002030-20021108000003

11. Highleyman L. Inflammation, immune activation, and HIV. BETA. 2010;2:12-26.

12. Ipp $\mathrm{H}$, Zemlin AE, Erasmus RT, Glashoff RH. Role of inflammation in HIV-1 disease progression and prognosis. Crit Rev Clin Lab Sci. 2014;2:98-111. http://dx.doi.org $/ 10.3109 / 10408363.2013 .865702$

13. Gaardbo JC, Hartling HJ, Gerstoft J, Nielsen SD. Incomplete immune recovery in HIV infection: Mechanisms, relevance for clinical care, and possible solutions. Clin Dev Immunol. 2012;1:1-17. http://dx.doi.org/10.1155/2012/670957
14. Hazenberg MD, Otto SA, Cohen Stuart JWT, et al. Increased cell division but not thymic dysfunction rapidly affects the T-cell receptor excision circle content of the naive T cell population in HIV-1 infection. Nat Med. 2000;6:1036-1042. http:// dx.doi.org/10.1038/79549

15. Junge $S$, Kloeckener-Gruissem $B$, Zufferey $R$, et al. Correlation between recent thymic emigrants and CD31+ (PECAM-1) CD4+ T cells in normal individuals during aging and in lymphopenic children. Eur J Immunol. 2007;11:3270-3280. http:// aging and in lymphopenic children.
dx.doi.org/10.1002/eji.200636976

16. Bains I, Thiebaut R, Yates AJ, Callard R. Quantifying thymic export: Combining models of naive $T$ cell proliferation and TCR excision circle dynamics gives an explicit measure of thymic output. J Immunol. 2009;7:4329-4336. http://dx.doi. org/10.4049/jimmunol.0900743

17. Kohler $\mathrm{S}$, Thiel A. Life after the thymus: $C D 31+$ and $C D 31$-human naive CD4+ T-cell subsets. Blood.2009;113:769-774. http://dx.doi.org/10.1182/blood-2008-02-139154

18. Levy $Y$, Lacabaratz C, Weiss L, et al. Enhanced T cell recovery in HIV-1-infected adults through IL-7 treatment. J Clin Invest. 2009;4:997-1007. http://dx.doi. org/10.1172/jci38052

19. Tanaskovic $S$, Fernandez $S$, Price $P$, Lee $S$, French MA. CD31 (PECAM-1) is a marker of recent thymic emigrants among CD4 ${ }^{+} \mathrm{T}$-cells, but not $\mathrm{CD} 8^{+} \mathrm{T}$-cells or $\gamma \delta \mathrm{T}$-cells, in HIV patients responding to ART. Immunol Cell Biol. 2010;88:321-327. http:// dx.doi.org/10.1038/icb.2009.108

20. Vianello F, Kraft YT, Mok YT, Hart WK, White N, Poznansky MC. A CXCR4-dependent chemo-repellent signal contributes to the emigration of mature single-positive CD4 cells from the fetal thymus. J Immunol. 2005;8:5115-5125. http://dx.doi. org/10.4049/jimmunol.175.8.5115

21. McFarland RD, Douek DC, Koup RA, Picker LJ. Identification of a human recent thymic emigrant phenotype. Proc Natl Acad Sci USA. 2000;8:4215-4220. http:// dx.doi.org/10.1073/pnas.070061597

22. Lee MS, Hanspers K, Barkers CS, Korn NP, McCune JM. Gene expression profiles during human CD4 T cell differentiation. Int Immunol. 2004;8:1109-1124. http:// dx.doi.org/10.1093/intimm/dxh112

23. Weinreich MA, Hogquist KA. Thymic emigration: When and how T cells leave home. J Immunol. 2008;4:2265-2270. http://dx.doi.org/10.4049/jimmunol.181.4.2265

24. Yang S, Liu F, Wang QJ, Rosenberg SA, Morgan RA. The shedding of CD62L (L-selectin) regulates the acquisition of lytic activity in human tumor reactive $T$ lymphocytes. PLoS One. 2011;6:1-10. http://dx.doi.org/101371/journal.pone.
0022560

25. Zhang L, Lewin SR, Markowitz M. Measuring recent thymic emigrants in blood of normal and HIV-1-infected individuals before and after effective therapy. J Exp Med. 1999;5:725-732. http://dx.doi.org/10.1084/jem.190.5.725

26. Harris JM, Hazenberg MD, Poulin JF, et al. Multiparameter evaluation of human thymic function: Interpretations and caveats. Clin Immunol. 2005;2:138-146. http://dx.doi.org/10.1016/j.clim.2004.12.008

27. Grossman Z. Immune reconstitution in HIV infection: How to measure thymic function? Clin Immunol. 2005;2:115-117. http://dx.doi.org/10.1016/j.clim.2005. 01.010

28. Khoury G, Rajasuriar R, Urquhart Cameron P, Lewin SR. The role of naïve T-cells in HIV-1 pathogenesis: An emerging key player. Clin Immunol. 2011;3:253-267. http://dx.doi.org/10.1016/j.clim.2011.09.002

29. BourgeoisC, Hao Z, Rajewsky K, Potocnik AJ, Stockinger B. Ablation of thymic export causes accelerated decay of naı"ve CD4 T cells in the periphery because of activation by environmental antigen. Proc Natl Acad Sci USA. 2008;25:8691-8696. http://dx.doi.org/10.1073/pnas.0803732105

30. Fink PJ, Hendricks DW. Post-thymic maturation: Young $T$ cells assert their individuality. Nat Rev Immunol. 2011;8:544-549. http://dx.doi.org/10.1038/ nri3028

31. Deeks SG, Kitchen CMR, HuaGuo LL, et al. Immune activation set point during early HIV infection predicts subsequent $C D 4^{+}$T-cell changes independent of viral load. Blood. 2004;4:942-947. http://dx.doi.org/10.1182/blood-2003-09-3333

32. Desai S, Landay A. Early immune senescence in HIV disease. Curr HIV/AIDS Rep. 2010;1:4-10. http://dx.doi.org/10.1007/s11904-009-0038-4

33. Papiernik M, Brossard $\mathrm{Y}$, Mulliez $\mathrm{N}$, et al. Thymic abnormalities in fetuses aborted from human immunodeficiency virus type 1 seropositive women. Pediatrics. 1992;2:297-301

34. Kourtis, AP, Ibegbu C, Nahmias AJ, et al. Early progression of disease in HIVinfected infants with thymus dysfunction. N Engl J Med. 1996;19:1431-1436. $\mathrm{http}: / / \mathrm{dx}$.doi.org/10.1056/NEJM199611073351904

35. Kolte L. Thymic function in HIV-infection. Dan Med J. 2013;4:B4622.

36. De Boer RJ. Estimating the role of thymic output in HIV infection. Curr Opin HIV AIDS. 2006;1:16-21. http://dx.doi.org/10.1097/01.COH.0000194105.12816.6a 